Procedures

\section{A Simplified approach for fabrication of custom tray for Facial prosthesis}

\author{
Jyotsna Vimal', Sunit Kumar Jurel2, Raghuwar Dayal Singh ${ }^{3 *}$ \\ and Pooran Chand ${ }^{4}$
}

'Junior Resident, King George's Medical University, UP, Lucknow, India

2Professor, Jr Grade, King George's Medical University, UP, Lucknow, India

${ }^{3}$ Professor, King George's Medical University, UP, Lucknow, India

${ }^{4}$ Professor and Head, King George's Medical University, UP, Lucknow, India

\section{Abstract}

Maxillofacial defects are very common and can be due to congenital defect, trauma, infections and neoplasms of facial region. These defects can be restored using different materials and retention methods to give a life like appearance. Rehabilitation of facial defect is a very challenging task. Every good prosthesis needs a skillful hand and it all starts with making a good impression of that defect and to proceed with the same. The aim of present paper was to present a simplified approach for the fabrication of custom tray to take facial impression of the patient with maxillofacial defect.

\section{More Information}

*Address for Correspondence: Dr. Raghuwar Dayal Singh, Professor, Department of Prosthodontics, King George's Medical University, UP, Lucknow 226003, India, Tel: +919919089227; Email: raghuwards@rediffmail.com

\section{Submitted: 25 August 2020 \\ Approved: 03 September 2020 \\ Published: 04 September 2020}

How to cite this article: Vimal J, Jurel SK, Singh RD, Chand P. A Simplified approach for fabrication of custom tray for Facial prosthesis. J Clin Adv Dent. 2020; 4: 028-029.

DOI: 10.29328/journal.jcad.1001021

Copyright: ( 2020 Vimal J, et al. This is an open access article distributed under the Creative Commons Attribution License, which permits unrestricted use, distribution, and reproduction in any medium, provided the original work is properly cited.

Keywords: Custom tray; Facial impression; Facial defect

(A) Check for updates

OPEN ACCESS

\section{Introduction}

Maxillofacial defects can be either congenital or acquired defect. Defect is not acceptable for the patient nor to the family of the patient in view of esthetic appearance and function. It hampers patient's life and socially unacceptable [1]. Defects can be due to squamous cell carcinoma or basal cell carcinoma [2]. Malignancies of the nasal septum are considered rare, and accounts for $9 \%$ of all cancers of nasal cavity [3]. Squamous cell carcinoma comprises about $66 \%$ of such lesions [4]. In the past several techniques have been defined for taking impression for facial defects using stock trays or not using stock trays [5-7]. Various materials have also been given in past with which impression can be made [8]. Kusum, et al. defined an innovative technique of taking facial impression by fabricating a stock tray of acrylic and with hinge attachment for accurate impression taking [9].

Most of the facial defect's impression can be obtained by using the present described technique. The stock tray, fabricated by this method can be used to take the final impression of the facial defect by using any suitable impression materials. This technique is simplified as well as cost effective.

The quality of life reduced due to such maxillofacial defect. Prosthetic management after trauma or surgery has been well documented. The purpose of this technical note was to describe a custom sculpted definitive facial custom tray for making facial impression.

\section{Technique}

1. Make the patient sit in a comfortable position on dental chair in at 45-degree angle.

2. Apply Vaseline over patient's face.

3. Then take a sheet of modelling wax (Pyrax Polymars, Estate Roorkee, India), put it in hot water and adapt over patient's face.

4. Adapt modelling wax all over the face (Figure 1).

5. Make this wax hard and rest it in a position.

6. To reinforce the wax, put a gauge dipped in plaster of paris and adapt it all over the modelling wax (Figure 2).

7. Let it set for about 24 hours.

8. Adapt a layer of self-cure acrylic ((Pyrax Polymars, Estate Roorkee, India) over the reinforced model.

9. This custom tray can now be retrieved from model as shown, and small holes with straight fissure bur can be made (Figure 3).

10. This tray can also be used in other patient with facial defects. 


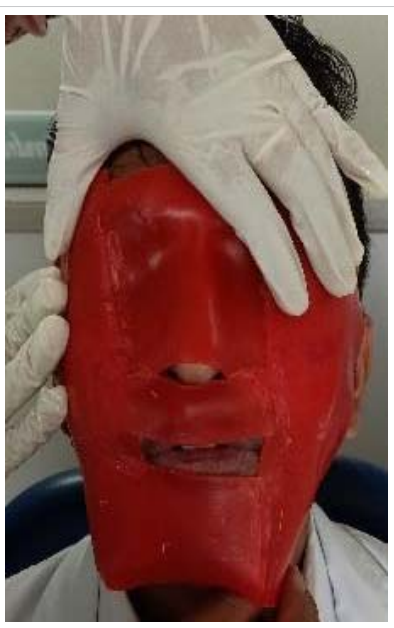

Figure 1: Modeling wax adaptation on the face.

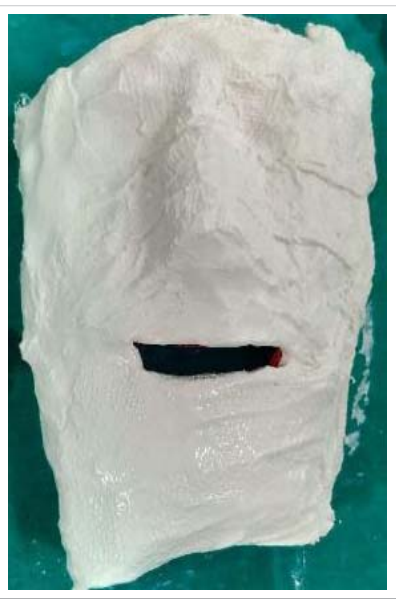

Figure 2: Plaster of Paris reinforced with gauge over the wax.

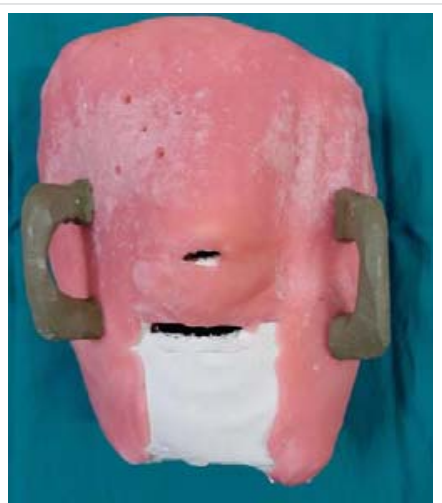

Figure 3: Final custom tray for facial impression.

\section{Discussion}

Facial defects result in esthetic, functional and psychosocial difficulties [10]. Surgical reconstruction techniques, prosthetic rehabilitation or a combination of both the methods to restore these facial disfigurements may improve the level of function and self-confidence for patients [11]. The site, size, and etiology of the defect, patient's age, general medical condition and desire are used to determine the methods of reconstruction $[12,13]$.
Prosthetic rehabilitation can be preferred due to probability of recurrence, complexity of the surgical reconstruction procedure, radiation therapy, and esthetic importance.

\section{Conclusion}

The approach for fabricating the custom tray, described in this article is simple and easy to use and can be used in any kind of extraoral defect in whom impression making is required. This custom tray can easily be used with any impression materials like irreversible hydrocolloid or elastomeric impression.

\section{References}

1. Fradis M, Podoshin L, Gertner R, Sabo E. Squamous cell carcinoma of the nasal septum mucosa. Ear Nose Throat J. 1993; 72: 217-221. PubMed: https://pubmed.ncbi.nlm.nih.gov/8482267/

2. Thawley SE. Comprehensive management of head and neck tomours, 2nd edition. St Louis: Elsevier. 1998; 526.

3. Beumer J, Curtis TA, Marunick MT. Maxillofacial rehabilitation: prosthetic and surgical considerations. Ishiyaku Euro America, St. Louis. 1998; 387-408.

4. Chalian VA, Drane JB, Standish SM. Maxillofacial Prosthetics. Baltimore: The Williams \& Wilkins Co.; 1971.

5. Jain K, Maru J, Shukla A, Vyas R, Jain PP. Nasal Prosthesis Rehabilitation: A Case Report S. J Indian Prosthodont Soc. 2011; 11: 265-269.

PubMed: https://www.ncbi.nIm.nih.gov/pmc/articles/PMC3205182/

6. Anantharaju A, Kamath G, Mody P, Nooji D. Prosthetic Rehabilitation of Oro-Nasal Defect. J Indian Prosthodont Soc. 2011; 11: 242-245. PubMed: https://www.ncbi.nlm.nih.gov/pmc/articles/PMC3205172/

7. Guttal SS, Patil NP, Shetye AD. Prosthetic rehabilitation of a midfacial defect resulting from lethal midline granuloma - a clinical report. J Oral Rehabil. 2006; 33: 863-867.

PubMed: https://pubmed.ncbi.nlm.nih.gov/17002746/

8. Phillips RW, Margetis PM, Urban JJ, Leonard F. Materials for the fabrication of maxillofacial prosthesis. In: Chalian VA, Drane JB, Standish SM (eds) Maxillofacial prosthetics. The Williams and Wilkins Company. Baltimore. 1972; 63-88.

9. Kusum CK, Indrajeet, Wankhade BG. A Simple technique to Fabricate a Facial Moulage with a Prefabricated Acrylic Stock Tray: A Clinical Innovation J Indian Prosthodont Soc. 2014; Suppl. 1: S341-S344. PubMed: https://www.ncbi.nlm.nih.gov/pmc/articles/PMC4502014/

10. Beumer J, Curtis TA, Marunick MT. Maxillofacial rehabilitation: prosthodontic and surgical considerations, 2nd edn. Ishiyaku Euroamerica, St Louis. 1996; 404-405.

11. Thomas KF. The art of clinical anaplastology. Techniques and materials guide for successful facial and somato prosthetic rehabilitation. 2nd Edition. London S Thomas. 2006; 16-22.

PubMed: https://www.ncbi.nlm.nih.gov/pmc/articles/PMC2994696/

12. Schaff NG. Maxillofacial prosthetics. In: Winkler S, editor. Essentials of complete denture prosthodontics. St. Louis Ishiyaku EuroAmerica. 1994; 403-415.

13. Roumanas E, Nishimura R, Beumer J, Moy P, Weinlander M, et al. Craniofacial defects and osseointegrated implants: Six-year follow-up report on the success rates of craniofacial implants at UCLA. Int J Oral Maxillofacial Implants. 1994; 9: 579-585 